\title{
Exopolymer production and microcolony formation by planktonic freshwater bacteria: defence against protistan grazing
}

\author{
Martin W. Hahnn ${ }^{1,3, *}$, Heinrich Lünsdorf ${ }^{2}$, Lore Janke ${ }^{1}$ \\ ${ }^{1}$ Max Planck Institute for Limnology, Department of Physiological Ecology, PO Box 165, 24302 Plön, Germany \\ ${ }^{2}$ German Research Center for Biotechnology, Division of Microbiology, Mascheroder Weg 1a, 38124 Braunschweig, Germany \\ ${ }^{3}$ Present address: Institute for Limnology, Austrian Academy of Sciences, Mondseestrasse 9, 5310 Mondsee, Austria
}

\begin{abstract}
The defence mechanisms of 2 novel bacterial isolates against protistan grazing were investigated in experiments with batch and continuous cultures. Strains MWH55 and MWH73 were isolated from the plankton of mesotrophic lakes using culture conditions with strong flagellate grazing pressure. The analysis of their 16S rRNA genes revealed that both strains belong to the Betaproteobacteria and demonstrated a close phylogenetic relatedness to bacteria previously detected by culture-independent methods in river biofilms and lake snow aggregates. Both strains showed a very weak sensitivity to flagellate predation, and both formed planktonic microcolonies that exceeded the upper size limit for ingestion by flagellates, and were thus protected from predation. These microcolonies consisted of cells embedded in a common exopolymeric matrix, yet lacked direct cell-to-cell contact between neighbouring cells. The structure of the exopolymeric matrix of the microcolonies was visualized by electron microscopy, while detection of exopolysaccharides by several fluorescently labeled lectins failed. The matrix possessed a complex 3-dimensional structure with strainspecific characteristics. Currently, it is not clear whether the 2 isolates possess a planktonic life strategy or whether they switch between sessile (biofilm or lake snow aggregates) and planktonic dispersal stages. In both cases, however, a low sensitivity of the planktonic stages to protistan predation is ecologically advantageous. The ability to form an exopolymeric matrix enabling the formation of predation-protected microcolonies is assumed to play a key role in the ecology of these bacteria.
\end{abstract}

KEY WORDS: Exopolymers - Bacteria $\cdot$ Predation protection - Flagellate grazing - Microcolony formation · Lectins

Resale or republication not permitted without written consent of the publisher

\section{INTRODUCTION}

Bacteria and other microorganisms produce a wide range of extracellular polymeric substances (exopolymers, EPS) composed of polysaccharides, proteins, nucleic acids, lipids, and other biological macromolecules (Wingender et al. 1999). When these substances accumulate on the cell surface of microbes, a matrix is formed that is usually characterized by high levels of water content and polysaccharide content and high viscosity. These accumulated EPS are often classified as capsules, sheaths or slime, dependent on their proximity or attachment to the cell wall (Beveridge \& Graham 1991).

EPS play a crucial role in the microbial formation of biofilms, which occur on almost all surfaces with envi- ronmental conditions favorable for microbial growth. EPS are also produced by microorganisms inhabiting environments lacking proper surfaces for biofilm formation (Decho 1990). For instance, in pelagic habitats, EPS was found in the form of freely suspended transparent exopolymeric particles (Schuster \& Herndl 1995), as capsules of single-celled bacteria (Stoderegger \& Herndl 2001), as an embedding matrix of planktonic cyanobacterial colonies (e.g. Microcystis spp.), as well as components of marine and lake snow aggregates (Grossart et al. 1997, Leppard 1999). For example, in a study of bacteria in the open ocean, Cowen (1992) observed, by use of transmission electron microscopy, that $80 \%$ of bacteria on sinking particles and $20 \%$ of bacteria in fine suspended particles produced EPS. 
The chemical composition of EPS varies. Exopolysaccharides, which are usually the major constituent of EPS, can contain a wide variety of sugar monomers. A combination of different sets of monomers plus the variety of chemical bonds potentially linking these monomers results in a high chemical diversity of EPS (Weiner et al. 1995). The species-specific and even the strain-specific chemical composition of EPS has been identified. Furthermore, synthesis and the composition of EPS was found to be influenced by environmental factors (e.g. Christensen et al. 1985, Allison et al. 1991, Beech et al. 1999).

A number of functions have been suggested for the roles of EPS. Several studies demonstrated that EPS play an important role in the interaction of plant, animal, and human pathogens with their hosts (e.g. Roberts 1995). Furthermore, the role of EPS in bacterial adherence and biofilm formation has received much attention (e.g. Christensen 1989). It was suggested that biofilm formation may offer individual bacteria nutritional advantages, protection from bacteriophages and bacterivorous protists, as well as resistance to antibiotics (Roberts 1996). Another well-investigated role of EPS, especially in soil bacteria, is protection against desiccation (Roberson \& Firestone 1992). Furthermore, Plante (2000) demonstrated that EPS capsules can reduce the susceptibility of some bacterial strains to digestive lysis by a deposit feeder (Arenicola marina: Polychaeta). On the other hand, the ecological role of EPS in non-pathogenic, non-biofilm-forming bacteria is not well understood.

In this study we investigated the role of EPS in the interaction of 2 bacterial strains, MWH55 and MWH73, with a bacterivorous protist. The strains were isolated from the pelagic zones of lakes, habitats where protists play a major role in the mortality of bacteria (Hahn \& Höfle 2001). We demonstrate that the investigated strains posses an unusually low sensitivity to flagellate grazing, and show that this trait is caused by the EPS-driven formation of planktonic microcolonies. For comparison, we included Pseudomonas sp. MWH1, another microcolony-forming strain (Hahn et al. 2000), in this study. Two other Pseudomonas strains (P. fluorescens and P. putida MM1), which are unable to form planktonic microcolonies, were used as predation-sensitive bacteria. Furthermore, we demonstrate that previously used stains for detection of EPS fail to stain the EPS of the 3 investigated microcolonyforming strains. This may indicate that the number of planktonic microcolony-forming bacteria is potentially underestimated in light-microscopical analysis of environmental samples.

\section{MATERIALS AND METHODS}

Isolation of bacterial strains. The bacterial strains MWH55 and MWH73 were separately enriched and isolated from the bacterioplankton of different mesotrophic lakes (Table 1) using culture conditions with high flagellate grazing pressure. Enrichment and isolation was performed in a similar manner as described previously (Hahn et al. 1999). An axenic culture of the flagellate Ochromonas sp. DS, and the complex media R2A (Reasoner \& Geldreich 1985) and NSY (containing in equal amounts nutrient broth, Soytone, and yeast extract, see Hahn et al. 2003) were used for enrichment and isolation. All isolates were finally cultured as pure cultures on $9 \mathrm{~g} \mathrm{l}^{-1} \mathrm{NSY}$ agar plates and stored at $-70^{\circ} \mathrm{C}$.

Microbial strains. Besides the 2 novel isolates, the microcolony forming Pseudomonas sp. MWH1, and the non-microcolony forming, grazing-sensitive, strains $P$. fluorescens DSM 500090T and P. putida MM1 (Christoffersen et al. 1997) were used in the experiments. The axenically grown bacterivorous nanoflagellate Ochromonas sp. DS, previously isolated from the pelagial of Lake Constance, (Hahn \& Höfle 1999) was used in predation experiments.

Determination and analysis of 16S rRNA gene sequences. Amplification, sequencing and alignment of the obtained sequences was performed as described previously (Hahn et al. 2003). Phylogenetic trees were

Table 1. Origin of investigated strains and their morphological features (+: present; -: absent). Cell-to-cell contact: direct cell-to-cell contact in microcolonies detected by epifluorescence microscopy

\begin{tabular}{|c|c|c|c|c|c|c|}
\hline Strain & Origin & $\begin{array}{l}\text { Isolation } \\
\text { medium }\end{array}$ & $\begin{array}{c}\text { Cell } \\
\text { morphology }\end{array}$ & $\begin{array}{l}\text { Cell-to-cell } \\
\text { contact }\end{array}$ & $\begin{array}{l}\text { Microcolony formation } \\
\text { in absence of grazers }\end{array}$ & Motility \\
\hline MWH55 & Lake Lanker $^{\mathrm{a}}$ & NSY & Rods & $-{ }^{b}$ & + & $-^{\mathrm{c}}$ \\
\hline MWH73 & Lake Schöhsee & $\mathrm{R} 2 \mathrm{~A}$ & Vibrios & $-^{\mathrm{b}}$ & + & $-^{\mathrm{c}}$ \\
\hline Pseudomonas sp. MWH1 & Lake Constance & NSY & Rods & + & - & $+^{\mathrm{d}}$ \\
\hline $\begin{array}{l}\text { a Sample used for enrichm } \\
\text { (Langenheder \& Jürgens } \\
\text { b Except dividing cells } \\
{ }^{\mathrm{c}} \text { Motility was not observec } \\
{ }^{\mathrm{d}} \text { Only single cells were m }\end{array}$ & $\begin{array}{l}\text { it stemmed from e } \\
\text { 001) } \\
\text { oy light microscop } \\
\text { ile (light microscor }\end{array}$ & $\begin{array}{l}\text { xperiment } \\
y \text {; flagella } \\
\text { oy) and po }\end{array}$ & $\begin{array}{l}\text { with already en } \\
\text { jere not detect } \\
\text { sessed flaqella }\end{array}$ & ched grazing & $\begin{array}{l}\text { rotected bacteria from La } \\
\text { icroscopy }\end{array}$ & ce Lanker \\
\hline
\end{tabular}


constructed by use of the ARB (www.arb-home.de, Strunk et al. 1998) and the MEGA2 (Version 2.1) software (www.megasoftware.net, Kumar et al. 2001). Neighbour-joining, maximum likelihood, and minimum evolution trees were calculated with and without a basefrequency filter specific for Betaproteobacteria. This filter excludes all alignment positions at which less than $50 \%$ of the sequences of the entire data set shared the same residues from the calculation. Bootstrapping of trees was performed with MEGA2 software. Sequence similarity values were calculated by the ARB software without base-frequency filters.

Microbial abundance and microcolony size. For determination of bacterial and flagellate abundance, samples were preserved with formaldehyde (2\% final concentration), stained with DAPI $\left(1 \mu \mathrm{g} \mathrm{ml}^{-1}\right)$, filtered on $0.2 \mu \mathrm{m}$ pore-size black polycarbonate filters (Nuclepore), and enumerated by epifuorescence microscopy. For estimation of size (determined as cells per microcolony) of MWH55 and MWH73 microcolonies, $10 \mu \mathrm{l}$ subsamples were diluted in $1 \mathrm{ml}$ sterile medium, stained, and filtered onto the $0.2 \mu \mathrm{m}$ filters. The low numbers of bacterial objects per filter resulted in large distances ( $>10$ times the size of the microcolonies) between the microcolonies on the filters. Thus, single-celled bacteria and microcolonies could be easily distinguished.

Detection of exopolymers. Direct staining with dyes: Staining with Alcian Blue (8GX; Sigma) and the fluorochrome calcofluor (Fluorescent Brightener 28; Sigma) was performed following the protocols of Logan et al. (1994) and Del Gallo et al. (1989), respectively.
Staining with fluorescein isothiocyanate (FITC)labelled lectins: A modification of the procedure outlined by Del Gallo et al. (1989) was used for staining the exopolymers with FITC-labeled lectins (Sigma) (Table 2). Samples of bacteria were filtered on $0.2 \mu \mathrm{m}$ pore-size black polycarbonate filters, washed with phosphate-buffered saline (PBS), covered for $30 \mathrm{~min}$ with $3 \mathrm{ml}$ of lectin solution $\left(100 \mu \mathrm{g} \mathrm{ml}^{-1}\right.$ in PBS), washed again with PBS, and finally stained with DAPI. Filters were transferred onto microscope slides and analyzed by an epifluorescense microscope. The staining procedure was performed with formaldehyde-preserved as well as non-preserved samples. Alternatively, staining of smears air-dried on microscope slides was attempted (original protocol by Del Gallo et al. 1989).

Chinese ink and fluorescent latex beads (negative staining): For indirect detection of exopolymers, suspensions of Chinese ink (Pelikan), as well as of $2.0 \mu \mathrm{m}$ fluorescent latex beads (Polysciences) were used. Samples were stained with DAPI and filtered onto $0.2 \mu \mathrm{m}$ filters. Immediately after filtration the dry filters were flooded either with $1 \mathrm{ml}$ ink suspension (5 drops $10 \mathrm{ml}^{-1}$ distilled water) or with $1 \mathrm{ml}$ of bead suspension $(8 \times$ $10^{7}$ beads $\mathrm{ml}^{-1}$ ). To avoid deposition of ink particles or beads between the filter and the microcolonies, the filter was covered while drawing the microcolonies by subpressure against the filter. The liquid of the suspensions was drawn through the filter while ink particles or beads settled in a very thin layer on the surface of the filter. Volume and concentration of both suspensions were optimized to create a layer thickness thin-

Table 2. Application of direct and indirect staining methods for detection of exopolymerous substances covering microcolonies of Pseudomonas sp. MWH1, Strain MWH55, and Strain MWH73 by transmission electron microscopy (TEM) and light microscopy $(\mathrm{LM}) .+$ : positive result; -: negative result; \pm : very weak bluish staining. Con A was bound to internal structures of formalinpreserved Ochromonas sp. DS cells

\begin{tabular}{|c|c|c|c|c|}
\hline Method & Specificity & Ionas sp. MWH1 & Strain MWH55 & Strain MWH73 \\
\hline Detection by TEM & - & + & + & + \\
\hline \multicolumn{5}{|c|}{ Negative staining (LM) } \\
\hline Chinese ink & - & + & + & + \\
\hline Beads & - & + & + & + \\
\hline \multicolumn{5}{|l|}{ Direct staining (LM) } \\
\hline Alcian blue & Acidic heteropolysaccharides & \pm & - & - \\
\hline Calcofluor & Neutral beta-glucans, cellulose & - & - & - \\
\hline \multicolumn{5}{|c|}{ Staining with FITC-labeled lectins (epifluorescence microscopy) } \\
\hline Con A & Alpha-D-mannose/glucose & - & - & - \\
\hline PHA-P & Oligosaccharides & - & - & - \\
\hline UEA-1 & L-fucose & - & - & - \\
\hline \multirow[t]{2}{*}{ BS-1 } & Terminal alpha-D-galactose and & & & \\
\hline & N-acetyl-alpha-D-galactosamine & - & - & - \\
\hline BS-2 & N-acetyl-D-glucosamine & - & - & - \\
\hline HPA & N-acetyl-alpha-D-galactosamine & $-{ }^{a}$ & - & - \\
\hline WGA & $\mathrm{N}$-acetyl-beta-D-glucosamine, neuraminic acid & - & - & - \\
\hline
\end{tabular}


ner than the thickness of microcolonies. Thus, in both cases, microcolonies were surrounded by the particle layers but not covered by them. Filters were transferred to frosted slides (Cyto-clear slide, Poretics) and inspected under UV-light (DAPI-stained cells; beads) and brightfield light illumination (ink). In contrast to other protocols using ink for negative staining, the procedure used avoided air-drying of bacteria, which may cause shrinkage of exopolymerous material.

Electron microscopy: Samples of cocultures of the bacterial strains with Ochromonas sp. DS were fixed with $2 \%$ (final concentration) glutaraldehyde. After sedimentation by $1000 \times g$ centrifugation, the sedimented microcolonies and flagellates were immobilized with $2 \%$ noble agar (Difco), stained for exopolymers with $0.4 \%(\mathrm{w} / \mathrm{v})$ thorium dioxide-100 $\mathrm{mM}$ sodium acetate, pH 3.0 (Strains MWH55 and MWH73, according to Groot [1981] and Winkler et al. [2001]) and conventionally with $1 \%$ (w/v) Alcian blue$100 \mathrm{mM}$ sodium acetate, $\mathrm{pH}$ 3.0, followed by conventional osmication (Pseudomonas sp. MWH1), and were finally embedded without further heavy metal treatment in an epoxy resin (Spurr 1969). Ultrathin sections, either non-poststained or poststained with $4 \%(\mathrm{w} / \mathrm{v})$ aqueous uranyl acetate and $0.3 \%(\mathrm{w} / \mathrm{v})$ lead citrate (Reynolds 1963), were examined with a Zeiss CEM 902 transmission electron microscope in the elastic bright-field mode.

Batch-culture experiments. Growth of Strains MWH55 and MWH73 in absence and presence of predators: Sterile NSY medium was 3:1 mixed with an axenic Ochromonas sp. DS culture (maintained in an inorganic basal medium). One-half of the mixture was sterile-filtered $(0.2 \mu \mathrm{m})$ and served as a medium for treatments without predation, the other half was used for treatments with predation. Both parts received NSY substrates to final concentrations of $18 \mathrm{mg} \mathrm{l}^{-1}$ (experiment with MWH55) and $9 \mathrm{mg} \mathrm{l}^{-1}$ (experiment with MWH73). Of these media, $50 \mathrm{ml}$ were poured into $100 \mathrm{ml}$ Erlenmayer flasks and inoculated with the bacterial strains. Treatments with Strains MWH55 and MWH73 were run in triplicate, those with control strains (Pseudomonas fluorescens and P. putida MM1) were not replicated. Experiments were performed at room temperature $\left(22\right.$ to $\left.25^{\circ} \mathrm{C}\right)$ without shaking.

Survival of non-growing populations of Strains MWH55 and MWH73 under high grazing pressure: Basal NSY medium (inorganic) containing flagellates $\left(2.6 \times 10^{4}\right.$ flagellates $\left.\mathrm{ml}^{-1}\right)$, but not supplemented with substrates, was prepared as mentioned above. This medium was inoculated with bacteria from stationary cultures grown in NSY medium in the absence of predators (9 $\mathrm{g}$ substrate $\mathrm{l}^{-1}$, room temperature, shaking). Incubation conditions during the experiment were as mentioned above.
Impact of presence/absence of predators on microcolony formation of Strains MWH55, MWH73 and Pseudomonas sp. MWH1: The bacterial strains were grown in the absence/presence of Ochromonas sp. DS (each treatment in triplicate) in 24-well tissue plates containing $4 \mathrm{ml}$ NSY medium (9 $\mathrm{mg} \mathrm{l}^{-1}$ ) per well. Flagellate concentrations in predation treatments were in the range of 2 to $4 \times 10^{4}$ Ochromonas $\mathrm{ml}^{-1}$. After $3 \mathrm{~d}$ incubation, $16 \mu \mathrm{l}$ of each culture was transferred to a fresh medium $(4 \mathrm{ml})$. Transfer was repeated 5 times, resulting for each strain in growth over 48 generations in the absence and presence of the flagellates.

Chemostat experiments. We ran 2 separate chemostat experiments (1 with Strain MWH55, 1 with MWH73) in a 1-stage chemostat system with 2 parallel reactors (working volume 0.5 l) (Hahn et al. 1999). Cultivation conditions were as follows: NSY medium containing $9 \mathrm{mg}$ substrate $\mathrm{l}^{-1}$, incubation at $15^{\circ} \mathrm{C}$, mixing by aeration, dilution rate $0.5 \mathrm{~d}^{-1}$. Each experiment consisted of 2 phases. In the first phase the bacteria were grow in the absence of predators, while the second phase started with inoculation with an axenic culture of Ochromonas sp. DS. Heat-killed food bacteria were added to the chemostat cultures (Hahn et al. 2000) to prove the food-limitation of flagellate growth.

Nucleotide sequence accession numbers. The sequences of the 16S rRNA genes of Isolate MWH55, Isolate MWH73, and Pseudomonas sp. Strain MWH1 were deposited under Accession Nos. AJ556799, AJ556800, and AJ556801, respectively.

\section{RESULTS}

Several bacterial strains were obtained from the pelagic zones of 2 lakes in northern Germany. Culture conditions with strong flagellate predation pressure were used for enrichment and isolation of the bacteria. The 2 strains MWH55 and MWH73 (Table 1) were selected for detailed characterization of their susceptibility to flagellate predation.

\section{Phylogenetic analysis of $16 \mathrm{~S}$ rRNA gene sequences}

Both MWH55 and MWH73 are Betaproteobacteria and cluster within the Comamonadaceae and Oxalobacteraceae, respectively. In all phylogenetic analyses, the sequence of Strain MWH55 clustered with 4 sequences of uncultured bacteria (Fig. 1) obtained from biofilm samples collected from 2 running-water systems (Brümmer et al. 2003). Sequence similarities within this cluster are in the range of 97.8 to $99.0 \%$. The closest related previously described species are Aquabacterium spp. (96.1 to $97.8 \%$ sequence similar- 


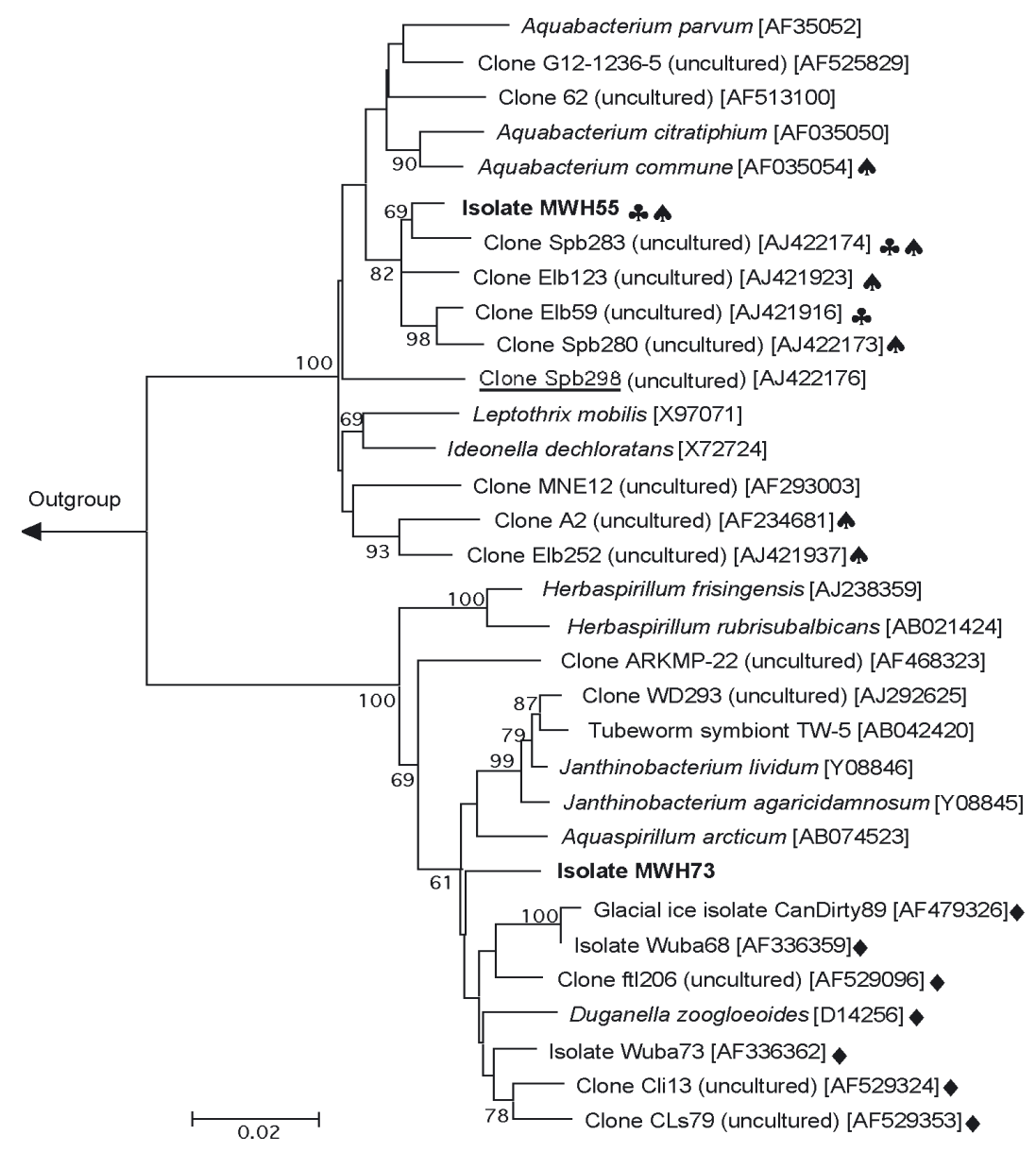

Fig. 1. Minimum evolution tree showing phylogenetic position of novel isolates. The tree was calculated with 1359 nucleotide sequence stretches of 16S rRNA genes. Sequence of Pseudomonas aeruginosa (M34133) served as outgroup (not shown). Bootstrap (1000 replicates) values $\geq 60 \%$ are shown; scale bar indicates $2 \%$ estimated sequence divergence. Sequences matching probes are marked with symbols: - Probe LSB65 (Schweitzer et al. 2001); \&: Probe beta 7 (Kalmbach et al. 1997); A : Probe beta 8b (Kalmbach et al. 1997). Clone Spb298 (underlined) is closely related $(98.2 \%$ sequence similarity) to 'Aquabacterium' sp. BETA3 (Pernthaler et al. 2001), which was not included in the tree due to its small sequence length (only $600 \mathrm{bp}$ )

\section{Impact of flagellate grazing on Strains MWH55 and MWH73}

The impact of grazing by the bacterivorous flagellate Ochromonas sp. DS was investigated in several experiments with batch and continuous cultures. In all experiments, under conditions supporting the growth of the bacteria (e.g. growth phase of batch experiments with available substrates; Fig. 2), flagellate grazing had only a weak or non-detectable influence on cell numbers of Strains MWH55 and MWH73. This weak impact on the bacterial populations was accompanied by a total lack or only weak growth of the flagellates (in batch and in chemostat experiments). In the chemostat experiment with Strain MWH55 (Table 3), the flagellate numbers dropped from 500 cells ml-1 to below the detection limit within $4 \mathrm{~d}$ of inoculation with the flagellate. In the experiment with MWH73, the flagellate was able to establish a relatively small population of 900 cells ml ${ }^{-1}$. The presence of this flagellate population had no significant influence on the MWH73 population (Table 3). In the separate chemostat experiments with Strains MWH55 and MWH73, the addition of alternative food (heat-killed, single-celled Pseudomonas putida cells) resulted in a quick increase in flagellate numbers, and a quick decrease in the added heat-killed bacteria. After exhaustion of the alternative food, flagellate numbers decreased. During the periods with higher flagellate numbers, no clear impact of the predator on bacterial numbers was observed.

In experiments with Pseudomonas fluorescens and $P$. putida, we observed a strong impact of the flagellate Ochromonas sp. DS on the bacterial populations (Fig. 2). Both tested ity), Ideonella dechloratans (97.7\%), and Leptothrix mobilis $(96.6 \%)$. The sequence of Strain MWH73 is affiliated with a branch of the Oxalobacteraceae which contains the species Janthinobacterium lividum $(97.7 \%$ similarity), J. agaricidamnosum (97.6\%), Aquaspirillum arcticum (97.0\%), and Duganella zoogloeoides (97.7\%). In contrast to Strain MWH55, the 16S rRNA sequence of Strain MWH73 did not show a consistent clustering. In some of the calculated trees the MWH73 sequence clustered with D. zoogloeoides (formerly Zoogloea ramigera), but in other trees these 2 sequences did not appear in a common cluster (e.g. Fig. 1). Based on the 16S rRNA gene sequence data, both isolates cannot be assigned to a previously described species.
Table 3. Chemostat experiments examining influence of predation by the bacterivorous nanoflagellate Ochromonas sp. DS on populations of Strains MWH55 and MWH73; 2 separate experiments with single bacterial strains were performed. Abundance data are means (SD) for periods of 5 (MWH55) or 7 (MWH73) days before and after addition of flagellates

\begin{tabular}{|c|c|c|c|}
\hline Experiment & $\begin{array}{l}\text { Abundance o } \\
\text { and after flac } \\
\text { Before } \\
\left(10^{6} \text { cells ml }{ }^{-1}\right)\end{array}$ & $\begin{array}{c}\text { bacteria before } \\
\text { ellate addition } \\
\text { After } \\
\left(10^{6} \text { cells ml }^{-1}\right)\end{array}$ & $\begin{array}{c}\text { Flagellates } \\
\left(10^{3} \text { cells ml }{ }^{-1}\right)\end{array}$ \\
\hline Strain MWH73 & $6.3(2.7)$ & $7.4(2.5)$ & $0.87(0.20)$ \\
\hline Strain MWH55 & $3.0(0.9)$ & $2.1(0.2)$ & $<0.1$ \\
\hline
\end{tabular}



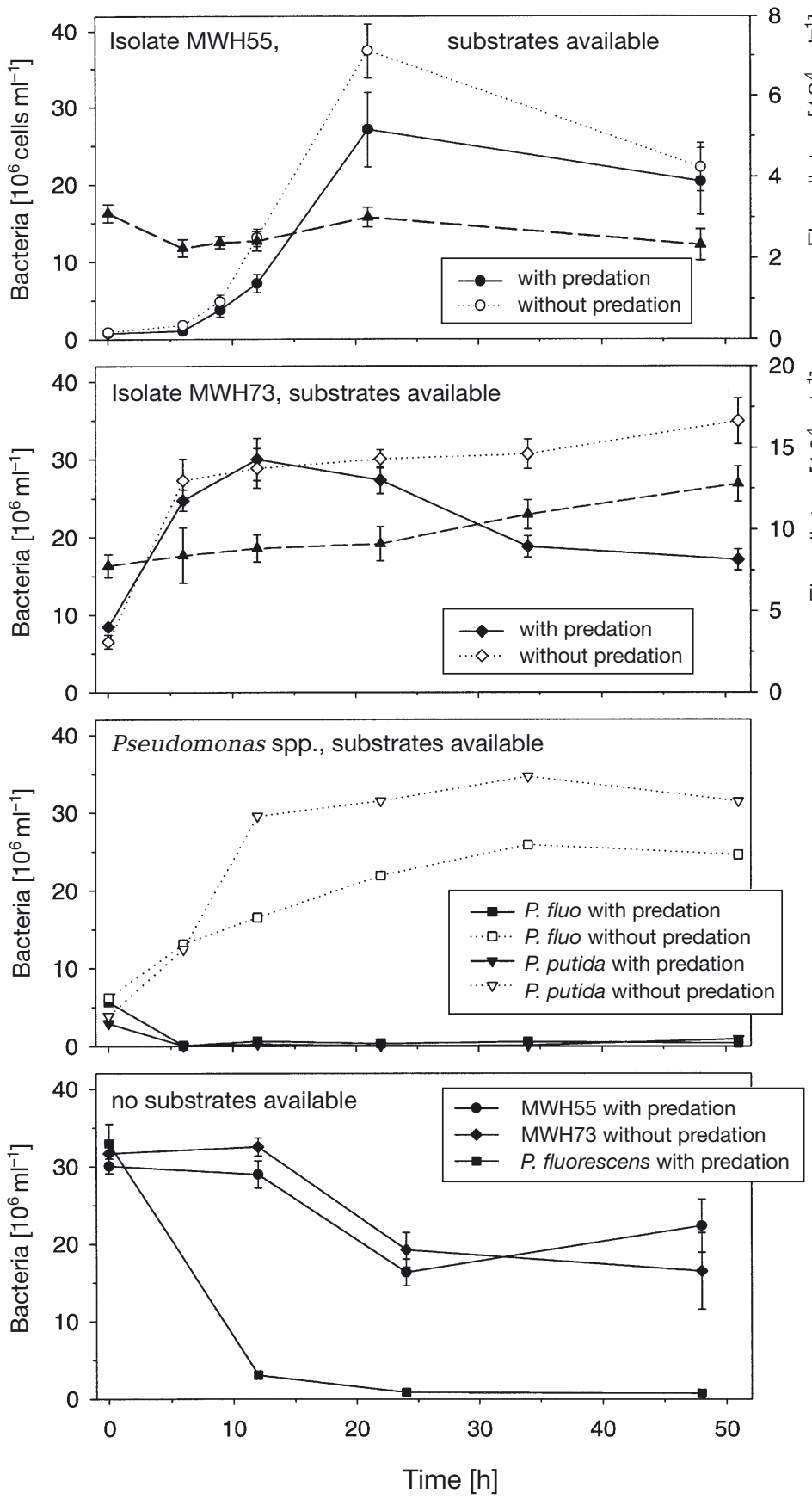

Fig. 2. Influence of grazing by the bacterivorous flagellate Ochromonas sp. DS on populations of Strain MWH55, Strain MWH73, Pseudomonas fluorescens, and P. putida MM1. In batch experiments (upper 3 graphs), medium contained substrates supporting growth of the bacteria. Total bacterial numbers determined in presence of flagellates are represented by open symbols, data from control experiments by closed symbols. Experiments with Strains MWH55 and MWH73 were performed in triplicate; control experiments were not replicated. Initial flagellate numbers in experiment with $P$. fluorescens (fluo) and $P$. putida MM1 were 7.1 and $6.6 \times 10^{4} \mathrm{ml}^{-1}$, respectively. In experiment with non-growing populations of Strains MWH55, MWH73, and $P$. fluorescens (bottom graph), initial flagellate numbers were 2.6, 2.6 and $2.8 \times 10^{4} \mathrm{ml}^{-1}$, respectively strains were not able to increase in number in the presence of the flagellate, but grew very well in its absence.

Even when no substrates were available (batch experiments without available substrates and stationary phase of the batch experiments with initially available substrates; Fig. 2 ), the impact of flagellate grazing on stationary-stage populations of Strains MWH55 and MWH73 was much less pronounced than on Pseudomonas fluorescens. Even under these experimental conditions the flagellates failed to consume a large fraction of the MWH55 and MWH73 populations.

The sensitivity of the non-growing MWH55 population to flagellate predation was influenced by growth conditions in the period before the population reached the stationary phase. When the population was grown in the absence of the flagellate, predation resulted in a decrease in cell numbers (Fig. 2, bottom graph). When the population was grown in the presence of the flagellate, no significant decrease in cell numbers was observed during the stationary phase (Fig. 2, top graph). In contrast, the grazing sensitivity of the non-growing MWH73 population was not influenced by previous growth conditions. The stationaryphase population of this strain showed a similar sensitivity to the flagellate predation in both experiments.

The cell sizes of the 4 investigated strains were similar. The cell length of MWH55 and MWH73 cells ranged from 1.5 to $2.5 \mu \mathrm{m}$, and for the Pseudomonas strains cell lengths of 1.5 to $3.0 \mu \mathrm{m}$ were observed. Cell size of all 4 strains were influenced by growth conditions.

\section{Formation of planktonic microcolonies}

In all experiments, Strains MWH55 and MWH73 formed planktonic microcolonies (Fig. 3), whilst Pseudomonas fluorescens and $P$. putida always grew exclusively as singlecelled morphotypes. The size of the MWH55 and MWH73 microcolonies was in the range of a few to $>100$ cells per colony; however, most of the observed microcolonies consisted of $<30$ cells. In contrast to the cells of Pseudomonas sp. MWH1 microcolonies (Hahn et al. 2000), the majority of cells contained in the microcolonies showed no direct cell-to-cell contact. When stained with the nucleic acid dye DAPI and viewed by epifluorescence microscopy, 


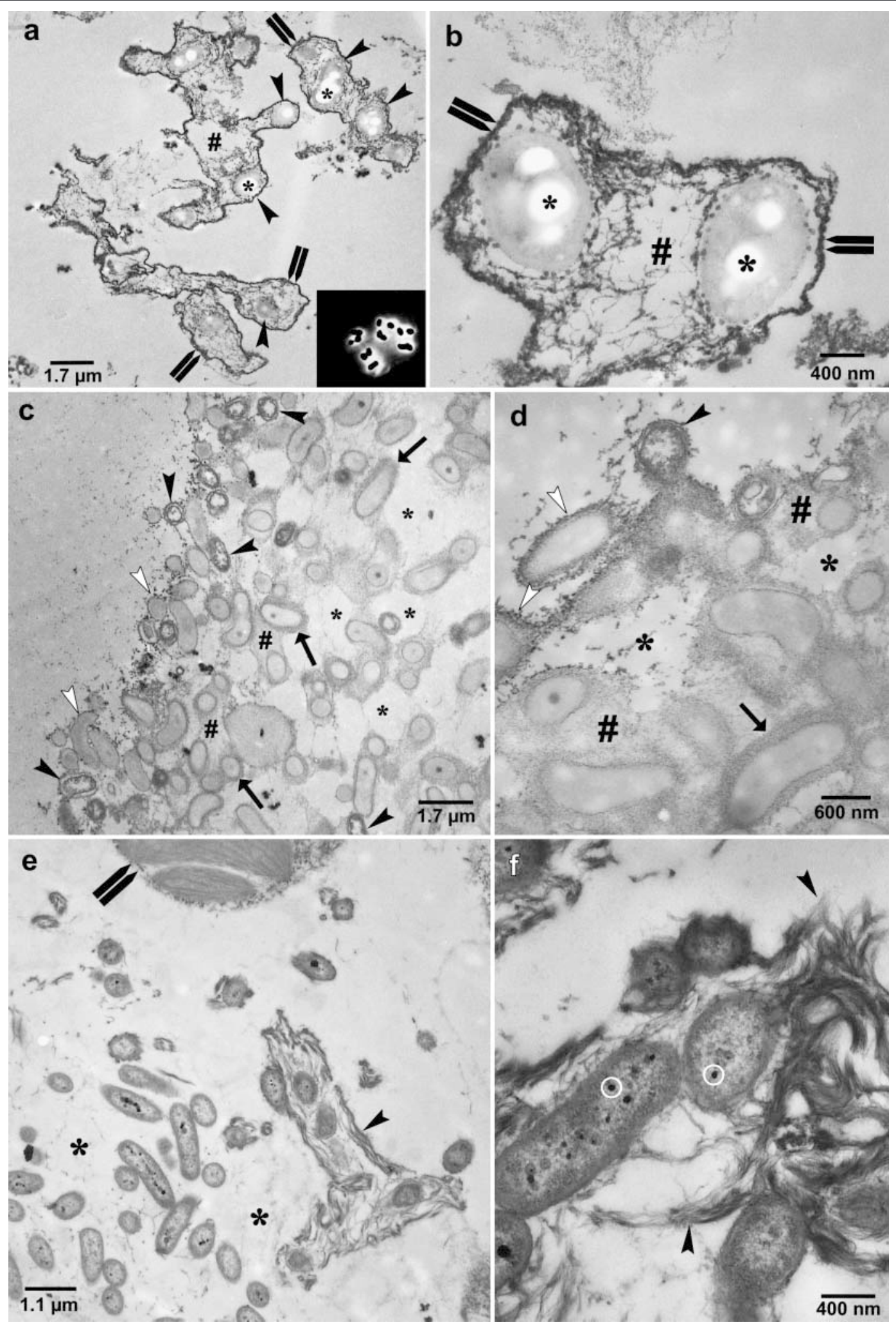

Fig. 3. Transmission electron micrographs of ultrathin sections of Strains MWH55, MWH73 and Pseudomonas sp. MWH1 grown under predation by the mixotrophic flagellate Ochromonas sp. DS. (a) Microcolonies of MWH55, formed in the presence of the flagellate; inset: light micrograph of microcolonies negatively stained with Chinese ink as low-resolution reference. Twin arrows: dense coat-like surface of MWH55 microcolonies; \#: open voids; arrowheads: MWH55 cells close to the coat-like EPS surface layer; asterisks: electron translucent storage granules. (b) Details of exopolymer (EPS)-fibrillar network and MWH55 bacterial cells. (c) Microcolonies of MWH73 in the presence of the flagellate. Area on the left is outside the microcolony. Matrix consisting of EPS and bacterial cells has a spongelike architecture. Open arrowheads: patchy, granular, dense EPS layer; black arrowheads: bacterial ghosts in the near-surface layer of the microcolonies; arrows; cells covered with thick and dense EPS; \#: low density EPS; asterisks: matrixfree voids.(d) Details of MHW73 cells and EPS surroundings. (e) Pseudomonas sp. MWH1 in vicinity of a flagellate cell (twin arrows) and microcolony architecture. Asterisks: homogenous, electron-translucent EPS matrix; black arrowheads: 'hairy' coat-like densely packed surface EPS. (f) Detailed view of ‘hairy' EPS matrix. Circles: electron-dense intracellular granules identified as polyphospates 
the microcolonies of both strains appeared as groups of cells with no visible contact between the cells. The cell-to-cell distances in microcolonies were frequently larger than the cell length. The space between the cells of DAPI-stained microcolonies appeared as empty spaces; thus, initially one did not obtain the impression that the grouped cells belong to a unit. Only the rare very large microcolonies ( $>30$ cells) appeared with a 3 -dimensional structure (cells in several layers).

In almost all experiments with Strains MWH55 and MWH73, the majority of the bacterial populations comprised planktonic microcolonies, with only a minority $(<30 \%$, in many samples even $<10 \%)$ as single cells. Microcolonies were observed in the presence and in the absence of the flagellates. In an experiment over 48 bacterial generations, however, a strong influence of the flagellate on the size of microcolonies and the proportion of single cells was observed (Fig. 4). In this experiment the populations of Strains MWH55 and MWH73 initially consisted mainly of small planktonic microcolonies ( 2 to 8 cells per microcolony). After 48 generations in the absence of predators, the size of microcolonies in both strains decreased and the proportion of single cells (initially $<10 \%$ in both populations) increased to $12 \%$ (MWH55) and $94 \%$ (MWH73) of the total bacterial numbers. In the presence of flagellates both strains showed the opposite response: mean size of the microcolonies increased and the percentage of single cells dropped to below detection limit.

A slightly different response was observed in Pseudomonas sp. MWH1. This strain formed micro-

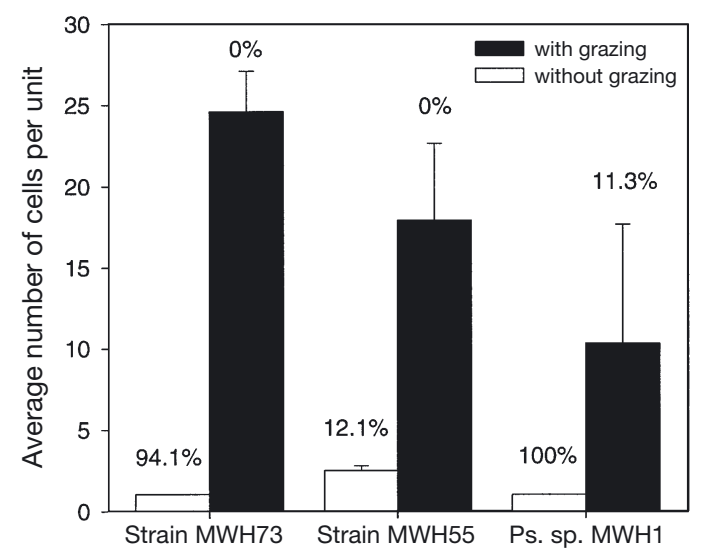

Fig. 4. Influence of flagellate grazing on formation and size of microcolonies formed by Strains MWH55, MWH73, and Pseudomonas sp. MWH1 after 48 generations in the presence/absence of the flagellate Ochromonas sp. DS. Bacteria were grown in batch cultures in a low substrate concentration medium. Single cells and planktonic microcolonies were each considered as 1 unit. An average of 1 cell per unit indicates that all cells were single cells and that no microcolonies were present. Bars represent averages (+SD) of 3 replicates; percentages above bars indicate average percentages of single cells in cultures colonies only in the presence of flagellates. In their absence only single cells and dividing stages were observed. The majority of single cells demonstrated motility, whilst no movement was observed for the microcolonies. In the other 2 strains, no motility was observed, either for single cells or for microcolonies.

\section{Detection and characterization of exopolymers}

Ultrastructural analysis. Fig. 3 shows ultrastructural data of ultrathin sections of bacterial microcolonies analyzed by transmission electron microscopy. The growth of the bacterial strains MWH55, MWH73 and Pseudomonas sp. MWH1 is shown in response to predation by the flagellate Ochromonas sp. DS. Fig. 3 $(\mathrm{a}, \mathrm{c}, \mathrm{e})$ shows the characteristic features of bacterial cells in association with exopolymeric substances. Based on binding of thorium stain or Alcian Blue to the negatively charged slime matrix, these polymers are ultrastructururally differentiated by their distinct densities according to the corresponding polymer chemistry. MWH55 produces a rather dense coat-like microcolony surface (Fig. 3a, b; twin arrows) about 40 to $50 \mathrm{~nm}$ thick. Below this, the intercellular slime matrix is characterized by a wide-spaced fibrillar meshwork, accompanied by open voids (Fig. 3a, b; \#). Often, individual cells (Fig. 3a; arrowheads) appear to be close to the dense coat-like EPS surface. Strain MWH55 produced electron translucent storage granules (Fig. 3a,b; asterisks) which, because of their characteristics, are assumed to be polyhydroxyalkanoate granules (Anderson \& Dawes 1990, Maehara et al. 2001). Electron-dense intracellular granules, identified as polyphosphates, could not be observed in either MWH55 strains, but were typically found inside Pseudomonas sp. MWH1 cells (Fig. 3f; circles).

In contrast to Strain MWH55, microcolonies of Strain MWH73 displayed a more complex architecture of the EPS matrix (Fig. 3c,d). A patchy, granular, dense EPS layer (Fig. 3c, di open arrowheads) of reduced thickness comprises the outermost surface of these microcolonies, and even the outermost individual cells reflect its fragility. Characteristically, within this near-surface layer, more bacterial ghosts can be found relative to the inner horizons (Fig. 3c, $d_{i}$ black arrowheads). Cells residing some 3 to $5 \mu \mathrm{m}$ inward of the microcolony surface produce a thick, about $150 \mathrm{~nm}$ to $200 \mathrm{~nm}$ dense, EPS layer (Fig. 3c,d; arrows). These thick-layered 'interior' cells are embedded within an EPS matrix of lower density, which forms the basic substance of the microcolonies' architecture (Fig. $\left.3 c, d_{i} \#\right)$, in alternation with matrix-free voids (Fig. 3c, di asterisks).

Finally, the microcolonies of Pseudomonas sp. MWH1 showed a distinctly different ultrastructure of their 
genuine EPS matrix. Here a clear-cut electron-dense layer of the outer microcolony surface is not obvious, and cells cluster homogeneously within an electrontranslucent EPS matrix (Fig. 3e; asterisks). Nevertheless, within this loosely packed matrix, areas exist that are characterized by cells embedded within a more dense EPS matrix of hairy appearance and a coat-like densely packed surface (Fig. 3e,f; black arrowheads). Epifluorescence microscopic images of microcolonies formed by Pseudomonas sp. MWH1 can be found elsewhere (Hahn \& Höfle 1999, Hahn et al. 2000).

Direct staining of exopolymers and analysis by light microscopy. In Pseudomonas sp. MWH1 microcolonies, direct staining with Alcian Blue resulted in a very weak signal from the cells forming microcolonies as well as from a small area surrounding the cells (Table 2). This weakly stained area was similar in size to the area not penetrated by ink or beads (see below). Neither single cells of Pseudomonas sp. MWH1, nor microcolonies or single cells of the strains MWH55 and MWH73 showed any staining by these dyes. Furthermore, none of the FITC-labeled lectins bound to the exopolymerous matrix of microcolonies of the 3 bacterial strains (Table 2). However, the Helix pomatia lectin HPA bound to the cell surface of Pseudomonas sp. MWH1 cells (to both single cells and to cells in microcolonies). Modifications of the staining procedure (slides instead of filters, non-preserved instead of preserved samples, prolongation of incubation with lectins, etc.) had no influence on the results.

Indirect detection of exopolymers. Negative staining with ink and beads demonstrated indirectly the existence of a transparent exopolymerous matrix surrounding the microcolonies of all 3 strains (Table 2). A single negatively (Chinese ink) stained microcolony of Strain MWH55 observed by light microscopy is also shown (in Fig. 3a; inset).

\section{DISCUSSION}

\section{Sensitivity of tested strains to flagellate grazing}

In comparison to other bacterial strains, Strains MWH55 and MWH73 demonstrated very weak sensitivity to predation by a bacterivorous flagellate (Fig. 2). In contrast to grazing-sensitive strains such as Pseudomonas putida MM1 and P. fluorescens, the MWH55 and MWH73 were able to increase in number in the presence of high numbers of predatory flagellates (Fig. 2). Furthermore, the flagellates not only failed to efficiently reduce the cell number of these strains, but also showed only weak growth or inability to grow when these bacterial strains were the sole food source (Fig. 2, and chemostat experiments). The observed strong increase in flagellate abundance after the addition of alternative food (chemostat experiments) demonstrated that they were food-limited in the sole presence of Strains MWH55 or MWH73, and that it is unlikely that their growth was inhibited by a toxic impact of the 2 microcolony-forming strains.

It should be noted that flagellate concentrations in our batch-culture experiments were up to 1 order of magnitude higher than usually observed in meso- to eutrophic lake ecosystems (Sanders et al. 1992). Furthermore, as demonstrated by previous experiments, the flagellate species used in our experiments is a predator of planktonic bacteria that is, in general, as efficient as other planktonic nanoflagellates (e.g. Hahn \& Höfle 1999, Posch et al. 1999, Boenigk \& Arndt 2000, Pernthaler et al. 2001).

We conclude that the flagellates were not able to efficiently prey on the bacteria due to a grazing protection mechanism preventing bacteria ingestion by the flagellates. In previous studies we observed a similar predation protection of the microcolony-forming strain Pseudomonas sp. MWH1 (Hahn \& Höfle 1999, Hahn et al. 2000), and other authors have observed the same protection in another Pseudomonas strain. (Matz et al. 2002). Predation protection of Pseudomonas sp. MWH1 was also highly efficient in comparison to other strains but less so in comparison to Strains MWH55 and MWH73. Furthermore, results from batch-culture experiments (Fig. 2) indicate that MWH55 is better protected than MWH73. This may be a result of its weaker tendency to grow as single cells (Fig. 4) and/or of its denser EPS structure (Fig. 4).

\section{Mechanism of predation protection and role of EPS}

Formation of planktonic microcolonies is a common trait of the 2 novel isolates and of Pseudomonas sp. MWH1. We previously demonstrated that this trait is responsible for predation protection of the colonial subpopulation of Pseudomonas sp. MWH1. Almost all microcolonies formed by all 3 strains were larger in size than the cell diameters of typical planktonic nanoflagellates $(<6 \mu \mathrm{m})$ and Ochromonas sp. DS (4 to $8 \mu \mathrm{m})$. Only in exceptional cases have nanoflagellates been reported to efficiently graze on prey larger than their cell diameter. Wu et al. (2004) observed successful predation by Ochromonas sp. DS on filamentous bacteria that had cell lengths of up to 2-fold the cell diameter of the flagellate. The cells of these bacteria were flexible in shape, enabling the flagellate to ingest these large bacteria. In contrast to these filamentous bacteria, the microcolonies of Strain MWH1 exceed in size the cell diameter of the flagellates in more than just one dimension. Therefore, it is highly unlikely that Ochromonas 
sp. DS or other nanoflagellates are able to ingest these microcolonies. We conclude that formation of such microcolonies is a general protection mechanism against nanoflagellates, which are frequently the most important bacterivores in the water column of aquatic ecosystems (Hahn \& Höfle 2001). Interestingly, in predation experiments with Ochromonas sp. and a Microcystis aeruginosa strain that in culture usually grows with a single-celled morphology, Burkert et al. (2001) observed microcolony formation by the cyanobacterium. As discussed previously for Pseudomonas sp. MWH1 (Hahn et al. 2000), the increase in size resulting from microcolony formation might increase the sensitivity to predation by larger grazers (e.g. omnivorous ciliates, cladocerans). The shift from potential grazing by nanoflagellates to grazing by grazers such as cladocerans, which belong to higher trophic levels, may have consequences for the channeling of carbon through the food web of aquatic ecosystems.

Another common trait of all 3 strains is that they tend to form populations consisting of colonial and single-celled subpopulations. While Pseudomonas sp. MWH1 formed planktonic microcolonies only in the presence of predators (Hahn et al. 2000 and present Fig. 4), the 2 betaproteobacterial strains can be considered constitutively microcolony-forming strains (Fig. 4). Populations of Strain MWH55 usually had the smallest proportion of single cells $(<15 \%)$, while predated Pseudomonas sp. MWH1 populations, with 30 to $80 \%$ (Hahn et al. 2000), had the highest proportion. These differences in the formation of presumably predation-sensitive single cells may explain the observed differences in grazing protection of the 3 microcolony-forming strains. The higher predation mortality of Pseudomonas sp. MWH1 may be balanced by the formation of motile stages, which have the potential to arrive chemotactically at microhabitats providing better growth conditions (e.g. higher substrate concentrations) (Blackburn et al. 1998).

By use of transmission electron microscopy (TEM), as well as by indirect staining, we have demonstrated that microcolonies of all 3 strains are embedded in an exopolymeric matrix. Cells in microcolonies of Strains MWH55 and MWH73 lack direct cell-to-cell contacts (Fig. 3); thus, at least in the case of these strains, the EPS matrix plays a crucial role in the formation and stability of the microcolonies. Therefore, the ability to produce such an embedding EPS matrix has to be viewed as the key feature in the predation defence of the Strains MWH55 and MWH73.

Interestingly, the 3 investigated microcolony-forming strains differ strikingly in the structure and architecture of the EPS matrices produced (Fig. 3). In the nearsurface zone of their microcolonies, 2 of the investigated strains possessed an EPS structure that was clearly different from that further inside the micro- colonies. This surface layer of the EPS matrix may play a specific role in the exchange of dissolved substances between the microcolonies and the environment. Consequently, a multifunctional role of the EPS matrix in the ecology of the investigated bacteria is possible.

\section{Ecology of Strains MWH55 and MWH73}

Both strains were isolated from the pelagic zones of lakes. This habitat is permanently occupied by some organisms forming planktonic colonies. In eutrophic freshwaters, colonial cyanobacteria such as Microcystis spp. occur (e.g. Kurmayer et al. 2003), and microcolony-forming picocyanobacteria seem to be typical inhabitants of oligo- to mesotrophic lakes (Callieri \& Stockner 2002, Crosbie et al. 2003). Both the picocyanobacterial and the Microcystis spp. colonies consist of cells usually not attached to each other, but embedded in a common EPS matrix (mucilage); thus their physico-chemical 'milieu' is similar to that of the microcolonies formed by Strains MWH55 and MWH73. The microcolonies of the 2 heterotrophic strains differ, however, in size from the cyanobacteria colonies (typically $>100$ cells per colony). This small microcolony size combined with the lack of cell-to-cell contact within the colonies and the transparency of the EPS matrix may explain the lack of reports of the occurrence of heterotrophic microcolonies in the pelagic zone. We investigated DAPI-stained samples from the pelagic of several lakes by epifluorescence microscopy, and found clusters of cells very similar to the microcolonies observed in our experiments. Due to lack of detection of an embedding EPS matrix, however, it remained difficult to classify these clusters as planktonic microcolonies. For a general evaluation of the ecological significance of planktonic microcolonies formed by heterotrophic bacteria, a protocol for direct staining of the exopolymers would be helpful.

In our experiments we used the 2 strains MWH55 and MWH73 as model organisms for the investigation of the influence of flagellate predation on planktonic microcolony-forming bacteria. Our results indicate that such microcolony-forming bacteria are relatively insensitive to flagellate predation. On the other hand, both investigated strains are phylogenetically related to bacteria that are not reported to have a planktonic life strategy (Fig. 1). The currently known closest relatives of Strain MWH55 are uncultured bacteria detected by cultureindependent methods in river biofilms grown on glass slides (Brümmer et al. 2003). While in Pseudomonas sp. MWH1 (Hahn et al. 2000) and Strain MWH73 we observed a weak tendency to form biofilms on glass surfaces (e.g. in chemostat vessels), no such ability was observed for Strain MWH55. In a phylogenetic analysis 
by Brümmer et al. (2003), most of the sequences clustering in our analysis with Strain MWH55 appeared in a cluster (RBF 5) which also contained 2 partial sequences that were not obtained from biofilms. Kalmbach et al. (1997) isolated several bacterial strains related to MWH55 from drinking-water biofilms. They developed several 16S rRNA probes targeting these isolates and used these probes for in situ investigations of drinking-water biofilms. The probes beta 7 and beta $8 \mathrm{~b}$ match the 16S rRNA sequence of MWH55 and other bacteria (Fig. 1). While the broader probe beta $8 \mathrm{~b}$ labeled up to $44 \%$ of all biofilm bacteria, the application of the more specific beta 7 probe in most of the investigation resulted in no detection of bacteria. Pernthaler et al. (2001) investigated predation by Ochromonas sp. DS on 'Aquabacterium' sp. BETA3. This is a phylotype related to MWH 55 (96.1\% sequence similarity) and closely related to the uncultured clone Spb298 (98.2\% sequence similarity) (Fig. 1). Pernthaler et al. (2001) observed neither microcolony nor biofilm formation by 'Aquabacterium' sp. BETA3, but reported a high sensitivity to predation by the flagellate.

In general, it is impossible to deduce from a close phylogenetic relationship that 2 bacteria share the same ecology. This is, for instance, well demonstrated by the close phylogenetic relationship of the freeliving species Janthinobacterium lividum and the tubeworm symbiont TW-5 (Fig. 1). Considering all these data, we cannot conclude that the Strain MWH55 is a strictly biofilm-forming bacterium normally absent from bacterioplankton of lakes.

The phylogenetic relationship of Strain MWH73 to its closest known relatives is not as clear as in the case of the Strain MWH55. Schweitzer et al. (2001) investigated the bacterial community of lake snow aggregates from Lake Constance by fluorescent in situ hybridization (FISH). They employed, amongst others, the probe LSB65 which targets several of the organisms closely related to Strain MWH73 (Fig. 1). They found that 10 to $50 \%$ of the probe-positive Betaproteobacteria (which frequently dominated the communities) matched this probe. Again, we cannot conclude that Strain MWH73 shares the same life strategy as its closest known relatives. We observed in the chemostat experiments that Strain MWH73 attached to the glass surfaces of the reactor; however, this attachment was very weak. After finishing the experiment the stability of the biofilm was tested by slight shaking the reactor, which resulted in complete detachment and disintegration of the biofilm.

Based on current data, we cannot conclude whether the 2 strains live exclusively as free planktonic microcolonies/single cells or whether they also possess biofilm- or aggregate-forming stages. Protection against protistan predation, however, is an important issue for permanently planktonic organisms, as well as for organisms possessing planktonic dispersal stages. Both, biofilm-forming and lake snow aggregate-inhabiting organisms need such dispersal stages for colonizing new sites/forming young aggregates. Thus, the formation of predation-protected planktonic microcolonies should be advantageous in the case of all 3 life strategies. We conclude that exopolymers and the formation of planktonic microcolonies play a key role in the ecology of Strains MWH55 and MWH73.

Acknowledgements. We would like to thank E. Barth for her skillful preparation of the electron microscopic specimen. The water sample used for the enrichment of Strain MWH55 was kindly provided by S. Langenheder. Strain Pseudomonas putida MM1 was provided by K. Jürgens. R. Kurmayer, J. Boenigk and 3 anonymous reviewers are acknowledged for providing valuable comments on an earlier version of this manuscript.

\section{LITERATURE CITED}

Allison DG, Brown MRW, Gilbert P (1991) Slow adherent growth modulates polysaccharide production by Pseudomonas aeruginosa. Biofouling 4:243

Anderson AJ, Dawes EA (1990) Occurrence, metabolism, metabolic role, and industrial uses of bacterial polyhydroxyalkanoates. Microbiol Rev 54:450-472

Beech I, Hanjagsit L, Kalaji M, Neal AL, Zinkevich V (1999) Chemical and structural characterization of exopolymers produced by Pseudomonas sp. NCIMB 2021 in continuous culture. Microbiology 145:1491-1497

Beveridge TJ, Graham LL (1991) Surface layers of bacteria. Microbiol Rev 55:684-705

Blackburn N, Fenchel T, Mitchell J (1998) Microscale nutrient patches in planktonic habitats shown by chemotactic bacteria. Science 282:2254-2256

Boenigk J, Arndt H (2000) Particle handling during interception feeding of four species of heterotrophic nanoflagellates. J Eukaryot Microbiol 47:350-358

Brümmer IHM, Felske A, Wagner-Döbler I (2003) Diversity and seasonal variability of $\beta$-Proteobacteria in biofilms of polluted rivers analyzed by TGGE and cloning. Appl Environ Microbiol 69:4463-4473

Burkert U, Hyenstrand P, Drakare S, Blomqvist P (2001) Effects of the mixotrophic flagellate Ochromonas sp. on colony formation in Microcystis aeruginosa. Aquat Ecol 35:9-17

Callieri C, Stockner J (2002) Freshwater autotrophic picoplankton: a review. J Limnol 61:1-14

Christensen BE (1989) The role of extracellular polysaccharides in biofilms. J Biotech 10:181-196

Christensen BE, Kjosbakken J, Smidsrod O (1985) Partial chemical and physical characterization of 2 extracellular polysaccharides produced by marine, periphytic Pseudomonas sp. strain NCMB 2021. Appl Environ Microbiol 50: $837-845$

Christoffersen K, Nybroe O, Jürgens K (1997) Direct measurement of bacterivory by protists using immunofluorescence labelling of ingested cells. Aquat Microb Ecol 13: $127-134$

Cowen J P (1992) Morphological study of marine bacterial capsules: implication for marine aggregates. Mar Biol 114 85-95 
Crosbie ND, Teubner K, Weisse T (2003) Flow-cytometric mapping provides novel insights into the seasonal and vertical distributions of freshwater autotrophic picoplankton. Aquat Microb Ecol 33:53-66

Decho AW (1990) Microbial exopolymer secretions in ocean environments: their role(s) in food webs and marine processes. Oceanogr Mar Biol Annu Rev 28:73-153

Del Gallo M, Negi M, Neyra CA (1989) Calcofluoar- and lectin-binding exocellular polysaccharides of Azospirillum brasilense and Azospirillum lipoferum. J Bacteriol 171: $3504-3510$

Groot GG (1981) Positive colloidal thorium dioxide as an electron microscopical contrast agent for glycosaminoglycans, compared with ruthenium red and positive colloidal iron. Histochemistry 71:617-627

Grossart HP, Simon M, Logan BE (1997) Formation of macroscopic organic aggregates (lake snow) in a large lake: the significance of transparent exopolysaccharide particles (TEP), phyto-, and zooplankton. Limnol Oceanogr 42: 1651-1659

Hahn MW, Höfle MG (1999) Flagellate predation on a bacterial model community: interplay of size-selective grazing, specific bacterial cell size, and bacterial community composition. Appl Environ Microbiol 65:4863-4872

Hahn MW, Höfle MG (2001) Grazing of protozoa and its effect on populations of aquatic bacteria. FEMS Microbiol Ecol 35:113-121

Hahn MW, Moore ERB, Höfle MG (1999) Bacterial filament formation, a defence mechanism against flagellate grazing, is growth rate controlled in bacteria of different phyla. Appl Environ Microbiol 65:25-35

Hahn MW, Moore ERB, Höfle MG (2000) Role of microcolony formation in the protistan grazing defence of the aquatic bacterium Pseudomonas sp. MWH1. Microb Ecol 39: 175-185

Hahn MW, Lünsdorf $H$, Wu QL, Schauer M, Höfle MG, Boenigk J, Stadler P (2003) Isolation of novel ultramicrobacteria classified as Actinobacteria from five freshwater habitats in Europe and Asia. Appl Environ Microbiol 69:1442-1451

Kalmbach S, Manz W, Szewzyk U (1997) Isolation of new bacterial species from drinking water biofilms and proof of their in situ dominance with highly specific 16S rRNA probes. Appl Environ Microbiol 63:4164-4170

Kumar S, Tamura K, Jakobsen IB, and Nei M (2001) MEGA2: molecular evolutionary genetics analysis software. Bioinformatics 17:1244-1245

Kurmayer R, Christiansen G, Chorus I (2003) The abundance of microcystin-producing genotypes correlates positively with colony size in Microcystis and determines its microcystin net production in Lake Wannsee. Appl Environ Microbiol 69:787-795

Langenheder S, Jürgens K (2001) Regulation of bacterial biomass and community structure by metazoan and protozoan predation. Limnol Oceanogr 46:121-134

Leppard GG (1999) Structure/function/activity relationships in marine snow. Current understanding and suggested research thrusts. Ann Ist Super Sanita 35:389-395

Logan BE, Grossart HP, Simon M (1994) Direct observation of phytoplankton, TEP and aggregates on polycarbonate filters using brightfield microscopy. J Plankton Res 16: $1811-1815$

Maehara A, Yamane T, Taguchi S, Doi Y (2001) Molecular characterization of a regulatory protein (PhaR) involved in PHA biosynthesis. RIKEN Review 42(12):77-80

Matz C, Deines P, Jürgens K (2002) Phenotypic variation in

Editorial responsibility: Karel Šimek,

České Budějovice, Czech Republic
Pseudomonas sp. CM10 determines microcolony formation and survival under protozoan grazing. FEMS Microbiol Ecol 39:57-65

Pernthaler J, Posch T, Šimek K, Vrba J and 5 others (2001) Predator-specific enrichment of Actinobacteria from a cosmopolitan freshwater clade in mixed continuous culture. Appl Environ Microbiol 67:2145-2155

Plante J (2000) Role of bacterial exopolymeric capsules in protection from deposit-feeder digestion. Aquat Microb Ecol 21:211-219

Posch T, Šimek K, Vrba J, Pernthaler J, Nedoma J, Sattler B, Sonntag B, Psenner R (1999) Predator-induced changes of bacterial size-structure and productivity studied on an experimental microbial community. Aquat Microb Ecol 18: $235-246$

Reasoner DJ, Geldreich EE (1985) A new medium for the enumeration and subculture of bacteria from potable water. Appl Environ Microbiol 49:1-7

Reynolds ES (1963) The use of lead citrate at high pH as an electron-opaque stain in electron microscopy. J Cell Biol $17: 208-212$

Roberson E, Firestone M (1992) Relationship between desiccation and exopolysaccharide production in soil Pseudomonas sp. Appl Environ Microbiol 141:2023-2031

Roberts IS (1995) Bacterial polysaccharides in sickness and in health. Microbiology 141:2023-2031

Roberts IS (1996) The biochemistry and genetics of capsular polysaccharide production in bacteria. Annu Rev Microbiol. 50:285-315

Sanders RW, Caron DA, Berninger UG (1992) Relationships between bacteria and heterotrophic nanoplankton in marine and fresh waters: an inter-ecosystem comparison. Mar Ecol Prog Ser 86:1-14

Schuster S, Herndl GJ (1995) Formation and significance of transparent exopolymeric particles in the northern Adriatic Sea. Mar Ecol Prog Ser 124:227-236

Schweitzer B, Huber I, Amann R, Ludwig W, Simon M (2001) $\alpha$ - and $\beta$-Proteobacteria control the consumption and release of amino acids on Lake Snow aggregates. Appl Environ Microbiol 67:632-645

Spurr AR (1969) A low viscosity epoxy resin embedding medium for electron microscopy. J Ultrastruct Res 26:31-43

Stoderegger KE, Herndl GJ (2001) Visualization of the exopolysaccharide bacterial capsule and its distribution in oceanic environments. Aquat Microb Ecol 26:195-199

Strunk O, Gross O, Reichel B, May M and 10 others (1998) ARB: a software environment for sequence data. Department of Microbiology, Technische Universität München, Munich

Weiner R, Langille S, Quintero E (1995) Structure, function and immunochemistry of bacterial exopolysaccharides. $\mathrm{J}$ Ind Microbiol 15:339-345

Wingender J, Neu TR, Flemming HC (1999) What are bacterial extracellular polymeric substances? In: Wingender J, Neu TR, Flemming HC (eds) Microbial extracellular polymeric substances. Springer-Verlag Berlin, p 1-19

Winkler J, Lünsdorf $\mathrm{H}$, Wirbelauer C, Reinhardt DP, Laqua $\mathrm{H}$ (2001) Immunohistochemical and charge-specific localization of anionic constituents in pseudoexfoliation deposits on the central anterior lens capsule from individuals with pseudoexfoliation syndrome. Graefe's Arch Clin Exp Ophathalmol 239:952-960

Wu QL, Boenigk J, Hahn MW (2004) Successful predation of filamentous bacteria by a nanoflagellate challenges current models of flagellate bacterivory. Appl Environ Microbiol 70:332-339

Submitted: September 16, 2003; Accepted: December 8, 2003 Proofs received from author(s): May 3, 2004 